\title{
STAGES AND FACTORS AFFECTING THE AUTHORISATION OF JAWI WRITING IN SIX YEARS STUDENTS OF THE SERI DUYONG NATION SCHOOLS OF MALAYSIA
}

\author{
${ }^{1}$ Ahlam Binti Ibrahim, ${ }^{2}$ Afriyanto Bin Emri \\ 1,2 Universiti Kebangsaan Malaysia, Bangi, Selangor Darul Ehsan, Malaysia \\ Emel: ahlamimtiaz@yahoo.com, afriyantobinemri@gmail.com
}

\begin{abstract}
Abstrak
The aim of the study is to identify the extent and level affecting Jawi mastery after the decline in Jawi achievement in Islamic teaching subjects, including the Jawi proficiency test in writing, spelling, multiple choice questions and Quranic writing. In this context, the main objective of this study is to identify the level of Jawi mastery, the difference between Jawi mastery factor and gender and Jawi mastery factor. The study is a quantitative survey and the selected study sample is a total of 72 students from Sekolah Kebangsaan Seri Duyong Melaka. The research tool is using questionnaires. The data obtained in this quantitative form were analyzed descriptively and side-effects (t-test) to test the null hypothesis (s) of the study. The findings suggest that there is no significant difference in the gender of students with the Jawi mastery factor. Finally, the purpose of this study is to improve the education system in respect to responses at the primary and secondary school levels.
\end{abstract}

Keywords: mastery, decline, factor, education system

\section{INTRODUCTION}

Jawi writing is an art of writing that has existed for centuries in the archipelago. Its origins are closely related to the arrival of Islam in the archipelago. The Jawi script derived from Arabic and Arabic letters is included in the Malay writing system. Jawi writing is also a type of writing that has a close connection with the development of Islam in Malaysia. Jawi writing is the earliest writing ever. This writing has developed since the time of the Kingdom of Johor, near the Islamic Empire and from the time of the Melaka kingdom, and from the time of Aceh in the 17th century.

Evidence of the existence of this writing in Malaysia is the discovery of the Terengganu inscription dated $702 \mathrm{H}$ or $1303 \mathrm{M}$ when the earliest Rumi writings were found in the late 19th century. This shows that Jawi writing reached this country before Rumi writing. The Jawi script is the official script of federated Malaysian states, but not of British control. Therefore, subjects 
should be taught in Java using effective methods and techniques so that students can master every skill in that subject. All the fifth grade students, target group, were exposed to Jawi writing while being in grade one through four.

The Jawi subject is an aspect that is emphasized throughout the Islamic education curriculum. The Jawi basics allow students to recognize and pronounce the Jawi letters, that is, the movements of the eyes and hands according to the size of the letters, read Jawi letters as well as simple syllables and words. Through Jawi's writing, the application of Islamic values can be strengthened. This is because according to the ideals of 'the Philosophy of National Education', Jawi's writing is the best way to try to implement Islamic values in students and society. Jawi's writing must be defended and sought, since it is a national heritage that must be dominated and maintained until the end of time.

Recently, what we have been seeing is the dominance and hobby of networking towards Jawi writing. There are no more papers that have the best inserts of the week in Jawi writing. In addition to the theme of Islamic education, using Roman script as a form of legal writing and promoting Jawi scripting, broadcast questions additionally use Rumi scripts. Officials starting with Tun Abdullah Haji Ahmad Badawi aimed to launch J-QAF applications in every primary school, as well as strengthening JAVI writings, al-Qur'an and Farad Ain. In this J-QAF application, elementary school students who are weak in Jawi mastery can be directed to small groups. Islamic and Jawi education textbooks are also available in Jawi script, and Brand New makes full use of Jawi script with primary school standard curriculum (KSSR) for those subjects.

\section{THEORETICAL FRAMEWORK}

The history of Malaysian education shows that Islamic education is taught in a variety of ways using books and texts written in Jawi. The effect of 
modifying the Arabic letters to suit the taste buds of Malaya to facilitate the teaching and learning process. For example, the letters Ga (j) were introduced based on the sounds of the letters Ka (ك) and Jim (飞), and Cha (ङ) based on the sounds of the letters Ta (ت) (ج). (Syed Muhammad Naqib Al-Atas, 1990). Therefore, the role of Jawi is the basic medium for teaching and learning Islamic education in today's Malaysian schools, especially the Koran.

The purpose of the Jawi lesson is to equip the students with Jawi writing and reading skills so that they can understand the various fields of knowledge in Islamic education. Going into the fields of Islamic education Education is a field and there are many methods and techniques to be used from time to time depending on the skill level of the students. However, it is difficult for students who are weak in going lessons because they are only given time to learn and practice answer writing skills that can only be learned during school hours or who spend more time in religious schools during their day. Also, allocating time for Jawi's rehabilitation is only 30 minutes a week, which is not enough, as the answer lessons require a lot of training from them, especially in terms of writing.

According to Amin, the weakness of elementary school students' writing skills is so significant that they cannot answer the questions that Joy characters use. Therefore, early Islamic education teachers need to overcome these factors, identify difficulties in writing Joy and create interest in students writing Joy. Some steps may be required. Must be taken On the other hand, according to Noorawati Saleemuddin (2000) in the study of Shazna Muhammad Saad (2009), learning to write, including Javanese characters, is not as easy as learning another language. The cognition of the eye-brain requires complete cognitive and psychometric, developmental, and motor sensory abilities to form and develop letter shapes. This is because JavaScript is the result of craftsmanship and art that has to be taught in the right way and technique from the beginning. 
Lack of dissemination of Jawi writing includes factors that cause a decrease in awareness in learning Jawi writing. students or the younger generation of Malaysians today have a weak spirit in learning Jawi. This weak spirit makes Jawi writing or reading feel foreign. Learning Jawi at this time is not interesting. Jawi teaching approach mostly still uses the old method that is with chalk and board. Interactive learning is very important to be given to students through interesting and fun applications or methods (Abdullah, 2008). The constraint of students who are lazy to write directly causes them to not want to write Jawi slowly (Graham, 2000). student laziness factors inhibit the learning process and mastery of learning Jawi. Jawi language teaching is better taught from an early age or kindergarten. Interesting teaching methods should be thought of so that students are motivated in learning the Javanese language (Nik Yaacob, 2007). Suhazlan et al. (2020) have examined the results of fingerprint test for second year students of Sekolah Kebangsaan Seksyen 19. The results show that there are 56\% of 157 students who do not have the skills to recognize and write connecting and non-connecting characters of Jawi script. researchers offer the application of jawi-AR with the aim of improving students' ability in understanding the jawi script.

Therefore, Jawi writing skills definitely need training and guidance to produce students who are capable and able to produce writing in perfect form using their senses and mental. As we already know that the decline in Jawi proficiency, al-Quran, Arabic and Fardhu Ain adolescence is very noticeable. This problem should be studied in an effort to find students 'perceptions of the j-QAF program that was introduced by the MOE in 2005. Here, researchers are interested in studying students' mastery of Jawi writing skills and the factors that influence it. Efforts to produce students who are able to produce writing with perfect form can not be continued if the students focused in this study, namely at Sekolah Kebangsaan Seri Duyung have problems mastering the skills of reading and writing Jawi. Year six 
students show that they have difficulty in writing Jawi and are weak in connecting Jawi single letters while teaching English loan word titles. Specifically, the objective of this study is to Identify students' level of mastery of learning Jawi, identify factors that influence the mastery of Jawi among students. And Identify significant differences between gender and Jawi mastery.

\section{METHOD}

This research was conducted using purposive sampling methods. This purposive sampling method is not a random sample that includes a specific sample taken for research purposes (Hamed Z., 2000). The purposive sampling method was chosen because it is appropriate to sample for a limited time. The design study of this uses questionnaire means as a research tool aimed at obtaining data as quantitative measures. The research location to obtain the respondents for this study is Sekolah Kebangsan Seri Duong (SKSD).

The population selected in this study was sixth-year students. A total of 72 students were identified as respondents for this study. To conduct this study, the researcher used the questionnaire as a research tool. The purpose of this questionnaire is to get feedback from sixth year students regarding this study. The questions provided in the questionnaire are organized according to the research questions for ease of reference. Researchers during the process of data collection and analysis. The use of questionnaires may improve the accuracy and veracity of the observations provided by the sample as they are not influenced by the researcher. According to Wiersma MW (1995), too much respondent data can be obtained in a short period of time and the responses obtained are more consistent for using questionnaires than other methods.

The researcher used a questionnaire instrument in this study. In general, this questionnaire tool consists of three parts, namely Parts A, B and C. Part I 
is a demographic section consisting of six questions in the form of answer selection. Questions in the form of answer selection are presented in this section because answers to these questions may be expected and limited. Questions in this section ask about gender, mother's job, father's job, etc. Part $B$ is the part that is more relevant to the evaluation studied by the researcher. In this section, the respondents conducted a test to see the level of efficiency of the students. Next, part of the researcher asked part $\mathrm{C}$ students about the factors they can master by going to sixth year students.

\section{RESEARCH FINDING AND DISCUSSION}

The results of the study show the proficiency of sixth-year students in the test, who passed the Jawi skills to answer the first research question. Section C of the questionnaire contains 10 questions. Questions in this section include the word witchcraft, compound letters, combination, conjunction, adjectives, word order, Arabic loan words, calligraphy, and references. Researchers analyzed the data using descriptive methods (percent) to determine the level of Jawi mastery among six-year-old students of Sekola Kebangsan Seri Duyong (SKSD). Based on the analysis, the researchers were able to determine the level of Jawi mastery among sixth-year students of Sekola Kebangsan Seri Duyong (SKSD). Regarding the study results, 32 people (44.4\%) achieved Grade A, 18 people Grade B (25\%), 8 people Grade C (11.1\%) and 14 people Grade D (19.4\%). ). Answering the first research question of the questionnaire given to respondents to assess the level of jaw mastery among sixth-year students, it was found that the total percentage of mastering students was 69.4\%. The Melaka State Department of Education (JPN) found that the percentage of students mastered in percentage grades was $94.5 \%$.

In this way, it clearly shows that there is a significant difference between the student skill level obtained from JPN and the research results. Evaluating jawi proficiency from JPN, $94.5 \%$ of students can learn jawi. This is a very 
high percentage and it seems that no student lost. On the other hand, the usual grade results received from teachers are weak or inadequate students. Researchers believe that there are many factors that allow teachers to opt out of NRD approval terms. These may include factors such as high workload, stress, and ineffective education and learning. It is the teacher's responsibility to do whatever it takes to improve student achievement and achievement in order to achieve the goals or objectives that NRD has set for the school.

According to Tan and Sabeha (1998), to achieve teaching objectives or improve teaching effectiveness, educators must "teach smart" in addition to "work hard". For example, the role of the teacher himself, a teacher should focus on his role as a planner, initiator and facilitator. Therefore, educators need to constantly innovate teaching and learning activities. There are many other initiatives that teachers can make in improving the achievement of students and not just let weak students get the grades they should not get. Therefore, this matter should not point fingers or blame the teacher alone. While it is the teachers who work hard and hard in improving student achievement and raising the name of the school. All parties whether teachers, schools or NRD should take this matter seriously and take remedial measures so as not to burden the other party.

Based on the analysis of the mean score, the researcher was able to identify the factors that students can master in Jawi among sixth year students at Sekolah Kebangsaan Seri Duyong (SKSD). Referring to the findings of the study in table 1 below, it was found that the mean of the overall factor of students' interest in mastering jawi is at a moderate level of 3.60. My item of interest in learning Jawi subjects is at a high level with a mean score of 4.12. Among the other items that are at a high level which tends to be interested in Jawi subjects are I am interested in writing Jawi (3.83), I am interested in Jawi writing (3.68), I am interested in writing Jawi because it is unique and challenging (3.85) and I have the determination to 
good at writing jawi (3.85). While the item that is at a moderate level is that I am good at writing Jawi (3.61), I like to read material in Jawi writing (3.67), and I often participate in competitions related to Jawi writing (2.69). Among the three items, my item is often involved in competitions related to Jawi writing with a mean score of 2.69 is the lowest item that is at a moderate level.

Table 1: Respondents' information on Jawi mastery factors (interest)

\begin{tabular}{llcc}
\hline No & \multicolumn{1}{c}{ Jawi Mastery Factors (Interest) } & Score & Interpretation \\
\hline B1 & I am interested in learning Jawi subjects & 4.12 & High \\
B2 & I am interested in writing Jawi & 3.83 & High \\
B3 & I am interested in Jawi writing & 3.68 & High \\
B4 & I am good at writing Jawi & 3.61 & Middle \\
B5 & I like to read material in Jawi script & 3.67 & Middle \\
B6 & I often get involved in related & 2.69 & Middle \\
& competitions & & \\
J7 Jawi writing & I am interested in writing jawi because it & 3.85 & High \\
& is unique and challenging & & \\
B8 & I have the determination to be good at & 3.85 & High \\
& writing Jawi & & \\
& Average & $\mathbf{3 . 6 0}$ & Middle \\
\hline
\end{tabular}

Next, table 2 below is a factor of students' attitude in mastering jawi among year six students. Items that are at a high level are a feeling of happiness when the teacher does not ask for writing jawi (4.25) and students always behave strangely while the teacher is teaching (3.94). The next item that is at a moderate level is Jawi writing is not important in the present (2.79), no one has the right to force me to learn Jawi (2.75), Jawi writing is difficult and complicated (2.67), Jawi is only used in the past (2.67) , as a Muslim I should master Jawi writing (3.10) and there is no difference whether I know or do not write Jawi (3.17). The mean score that is at the lowest level is that Jawi writing items are difficult and complicated (2.67) and Jawi is only used in the past (2.67). The mean that is at this low value shows that students do not agree that Jawi writing is difficult and complicated and Jawi is only used in the past. 
Table 2: Respondent information on Jawi mastery factors (attitude)

\begin{tabular}{clcc}
\hline No & \multicolumn{1}{c}{ Faktor Penguasaan Jawi(Sikap) } & Score & Interpretation \\
\hline B9 & Jawi writing is not important nowadays & 2.79 & Low \\
B10 & $\begin{array}{l}\text { I always behave strangely while the } \\
\text { teacher is teaching }\end{array}$ & 3.94 & High \\
B11 & $\begin{array}{l}\text { No one has the right to force me to learn } \\
\text { Jawi }\end{array}$ & 2.75 & Middle \\
B12 & Jawi writing is difficult and complicated & 2.67 & Middle \\
B13 & Jawi was only used in ancient times & 2.67 & Middle \\
B14 & As a Muslim I should master Jawi writing & 3.10 & Middle \\
& & & High \\
B15 & $\begin{array}{l}\text { Feeling happy when the teacher does not } \\
\text { ask to write jawi }\end{array}$ & 4.25 & Middle \\
B16 & $\begin{array}{l}\text { There is no difference between knowing } \\
\text { or not writing jawi }\end{array}$ & 3.17 & Middle \\
\hline
\end{tabular}

Based on table 3 is a motivational factor for students in mastering jawi among sixth year students. Based on the interpretation of the mean, it was found that the mean that is at a high level is item 22, namely students trying to learn to write Jawi because my friends are good at writing Jawi (3.83). The next item that is at a moderate level is that I have tools / media / software related to Jawi writing (3.67), if I participate in the Jawi writing competition, I will try to win it (3.67), teachers use teaching aids during teaching and learning sessions ( 3.50 ), parents always encourage me to learn Jawi as best as possible (3.31) and teachers give encouragement and enthusiasm to write Jawi (2.75). While the mean score is at a low level is students have Jawi reading material at home $(2.26)$.

\begin{tabular}{clcc}
\multicolumn{4}{c}{ Table 3: Respondent information on Jawi mastery factors (motivation) } \\
\hline Bil & Jawi Mastery Factors (Motivation) & Score & Interpretation \\
\hline B17 & I have Jawi reading material at home & 2.26 & Low \\
B18 & $\begin{array}{l}\text { I have tools / media / software related to } \\
\text { Jawi writing }\end{array}$ & 3.67 & Middle \\
B19 & $\begin{array}{l}\text { My parents always encouraged me to } \\
\text { learn Jawi as best I could }\end{array}$ & 3.31 & Middle \\
If I participate in the Jawi writing & 3.67 & Middle \\
\hline
\end{tabular}


Binti Ibrahim, A., Bin Emri, A. (2020). STAGES AND FACTORS AFFECTING THE AUTHORISATION OF JAWI WRITING IN SIX YEARS OF THE SERI DUYONG NATION SCHOOLS OF MALAYSIA. Jurnal Tatsqif, 18 (1), 97-110. https://doi.org/10.20414/itq.v17i2.2542

$\begin{array}{llcc}\text { B21 } & \begin{array}{l}\text { Teachers give encouragement and } \\ \text { encouragement to write Jawi }\end{array} & 2.75 & \text { Middle } \\ & \begin{array}{l}\text { I try to learn to write Jawi because my } \\ \text { friends are good at writing Jawi } \\ \text { Teachers use teaching aids during }\end{array} & 3.83 & \text { High } \\ \text { B23 } & & 3.50 & \text { Middle } \\ & \text { teaching and learning sessions } \\ \text { Average } & \mathbf{3 . 2 8} & \text { Middle }\end{array}$

The result of the overall mean analysis of the three factors, namely interest, attitude and motivation in mastering the highest jawi is the interest factor of 3.60. While the lowest is the attitude factor which is 3.17. This shows that the interest factor is more likely to master Jawi among sixth year students. While the attitude factor is more inclined in identifying the weaknesses of sixth year students of Sekolah Kebangsaan Seri Duyong, Melaka. Based on the results of the findings to answer the second research question that is "what are the factors that students can master among students in the sixth year of Sekolah Kebangsaan Seri Duyong (SKSD)", Jawi especially in terms of Jawi writing itself and students have the determination to be good at writing Jawi in the future. Such a thing is not a concern for the school because the students themselves are serious, determined and determined to improve themselves in the subject of Jawi.

Outcomes in terms of interest rate factors that are at the lowest middle level, i.e. I often go with an average of 2.69 to participate in writing related competitions. This shows that students are less interested in science related activities related to answer writing, which are usually held at any school, district or even state level. Educational activities are af f-class activities held in religious programs or J-Kaif aims to improve the talents of students in the field of religion to generate noble, authentic and skilled human capital. The results of this study show that students are less interested or inclined to participate in the Jawi competition. Probably due to lack of awareness or encouragement by teachers or lack of skills and confidence in students. All of these factors depend on the teacher when it comes to shaping students aged 
seven and over. Teachers should guide students and actively develop so that students 'performance in pedagogy is consistent with influence in religion.

Furthermore, in terms of attitude factors, the results of the study are still difficult for students to consider and are not complicated if studied diligently. This is due to the lower average score of 2.67. Other than that, the average score equivalent to the item means that students do not agree that jawi script has been used in the past. If they are valued and researched against current media, there are magazines, ads, banners, billboards, etc. They still use Javascript. Production is still available but may be limited due to the impact of the purchase on the community.

The attitude of students who have a high mean score value is that students feel happy when the teacher does not ask to write Jawi (4.25). In the opinion of the researcher, the average of these attitudes is possessed by every student, which is to feel happy when the teacher does not ask to write Jawi. So it is the responsibility of teachers to further diversify teaching and learning methods so that students like this do not get lazy and lag behind in Jawi subjects. The intelligence and proactiveness of a student depends on the teacher in shaping the future of the students. Motivation is the most important element in increasing students' self-confidence and ability, especially in education. The application of motivational values among teachers to students such as support, encouragement and enthusiasm will produce students who are versatile and active in teaching and learning sessions in the classroom. Following from the findings of the study in terms of motivational factors, the highest item is that students try to learn to write Jawi because my friends are good at writing Jawi (3.83). The item is more geared towards the peer factor in the classroom. In learning, normally, students will always strive to compete with friends who are smarter and smarter than him. So it is a necessity for teachers to mix students who have different levels of achievement in the same class so that this factor of healthy peer competition can be created. Pupils will be more enthusiastic, active and 
Binti Ibrahim, A., Bin Emri, A. (2020). STAGES AND FACTORS AFFECTING THE AUTHORISATION OF JAWI WRITING IN SIX YEARS OF THE SERI DUYONG NATION SCHOOLS OF MALAYSIA. Jurnal Tatsqif, 18 (1), 97-110. https://doi.org/10.20414/itq.v17i2.2542

always want to move forward to improve achievement in jawi mastery. While the lowest item in the mastery factor in terms of motivation that I have reading material at home recorded a mean score value of 2.26 . The results of these mean values show that the value and support from parents is less.

This is because parents do not give students the risk or incentive to buy material related to Jawi reading material in magazines and newspapers, reference books, academic books, etc. Researchers don't just raise their finger at parents because there can be many unknown causes or specific reasons. Among them, in terms of financial factors, there are some parents who can provide Jawi's reading material and there are also those who cannot afford it. Therefore, parents are responsible for educating and shaping the best future for their children. Significant differences in Jawi's domain factors by gender. The alpha-level test (0.05) was used to analyze the difference in means between the two variables. The difference in the domain of Jawi according to the gender of men and women is seen from three factors, namely, interest, attitude and motivation. The results of the data analysis showed that there is no significant difference in the mastery of Javi by students and students. The next is a value of $t=0.626$, while the critical value of 0.534 is greater than 0.05. Therefore, it can be concluded that there is no significant difference in Javi's domain factors according to gender and that they are shown in Table 4.

Table 4: Differences in Jawi mastery factors by gender

\begin{tabular}{lccllll}
\hline Factor & N & Min & $\begin{array}{c}\text { Standard } \\
\text { deviation }\end{array}$ & $\begin{array}{c}\text { Degree of } \\
\text { freedom } \\
\text { (df) }\end{array}$ & T & Significant \\
\hline Male & 28 & 3.57 & 0.310 & 70 & 0.626 & 0.534 \\
Female & 44 & 3.62 & 0.352 & & & \\
\hline
\end{tabular}

\section{CONCLUSION}

The Ministry of Islamic Affairs and the Ministry of Ethical Education, the State Department of Education, the Department of Teachers Education and the Malaysian Prime Minister's School's desire to realize the idea are very proud of the efforts of the Malaysian Ministry of Education at the ministry 
level. Due to what, in particular, the implementation of Joy Study is to help students who have stopped recognizing the answer writing. Will support going to Malay as a writing on the living island. And this legacy will last forever because the pride of the community will be inherited by the children. Peng Ji also hopes that there will be more details on other aspects of the Model Dello JQAF program in the future to improve the knowledge of Malaysians. This study is just a general survey of Sekolah Kebangsaan Sri Duyong Melaka's sixth-year students and cannot be replicated elsewhere. Therefore, the researcher hopes that if other research has been done on learning to see, some improvements need to be made so that the study can be continued from time to time.

\section{REFERENCES}

Abdullah Ali Hassan. (1980). The development of Islamic Education in Kelantan dalam Tamadun Islam di Malaysia. Kuala Lumpur: United Selangor.

Abdul Ghafar, M. N. (1999). Penyelidikan Pendidikan, Universiti Teknologi Malaysia.

Abdullah N. A. et al. (2008) A Toolkit Design Framework for Authoring Multimedia Game- Oriented Educational Content, 8th IEEE International Conference on Advanced Learning Technologies, IEEE Press, New York. pp.144-145.

Asyraf Ridwan Ali \& Berhanundin Abdullah. (2015). Falsafah Pendidikan Jawi dalam memperkasakan tamadun Islam di Malaysia. Proceedings of ICIC2015-International Conference on Empowering Islamic Civilization in the 21st Century. Malaysia: Universiti Sultan Zainal Abidin, 6-7 September 2015. ISBN: 978-967-13705-0-6.

Devaraju, A., et al. (2007), MyLexic: An Assistive Multimedia Courseware for Teaching and Reinforcing Basic Reading Skills among Dyslexics, World 
Conference on E-Learning in Corporate, Government, Healthcare, \& Higher Education. Quebec City, Canada.

Graham, S., et al.(2000) Is handwriting Casually Related to Learning to Write? Treatment of Handwriting Problems in Beginning Writers, Journal of Educational Psychology,vol. 92, pp. 620-633.

Hamed, Z. (2000). Teknik Pengumpulan Data Dalam Penyelidikan. PTS Profesional Publishing Sdn.Bhd.

Kamaruddin, N., (2010). Challenge of Malaysian Developers in Creating Good Interfaces for Interactive Courseware, The Turkish Online Journal of Educational Technology, Vol 9 (1). pp.37-42.

Norhawati Salimuddin (2000). Penyelidikan Pendidikan. Edisi Pertama.

Skudai: Universiti Teknologi Malaysia.

Nik Yaacob, N. R., (2007), Pengusaan Jawi dan Hubungan dengan Minat dan Pencapaian Pelajar dalam Pendidikan Islam, Jurnal Pendidik dan Pendidikan.vol.22.pp.161-172.

Shazana Muhamed Sa'ad (2009). Kesan Penggunaan Alat Bantu Mengajar (ABM) Terhadap Pencapaian Akademik Pelajar Di Kolej Komuniti Gerik. Universiti Tun Hussein Onn Malaysia: Tesis Sarjana.

Syed Naquib al-Attas (1990). Islam dalam sejarah dan kebudayaan Melayu. Petaling Jaya: Angkatan Belia Islam Malaysia.

Suhazlan, B, S., et al. (2020). Jawi-AR Apps: Single Jawi Character Connecting Method to single words using AR Technology. Conference Series: J. Phys.: Conf. Ser. 1529032001.

Wiersma, M.W. (1995). Research Methodology In Education. 5th ed. New York:Printice Hall

Yusoff , M. A., (2005). Perkembangan Tulisan Jawi dan Aplikasinya Dalam Masyarakat Islam di Malaysias. vol 21. pp 23-38. 